\title{
A Review of Pottery Cultures in Central Anatolia during the Middle Iron Age, taking Yassıhöyük (Kırșehir) as a Case Study
}

Imagine a borderline in Central Anatolia along with the course of Halys River during the Middle Iron Age (MIA) (about 9th-7th c. BC) separating two different pottery cultures. H. Genz proposes this invisible border starting from the direction of Konya through the Salt Lake up to the north of the Halys River to distinguish two main pottery zones: 'monochrome grey wares' observed intensively in Gordion on the west under Phrygian rule (Region 1) and 'painted pottery with matt dark paint' seen in Boğazköy on the east where no political entity has been identified so far (Region 2) (2011: 348-349). Genz also points to a discernible interaction between those regions (Region 1 and 2) (2011: 349). Yassıhöyük (Çayağz1 village near Kırșehir) is very close to this invisible border, on the southwestern part of the Halys bend (Omura, 2008: 99). The site has been excavated by the Japanese Institute of Anatolian Archaeology under the direction of Masako Omura since 2009.

When the site's location is viewed in terms of political landscape during the MIA, Yasshöyük is again on the borderline between the west of the river with Phrygian rule (Region 1) and the south of the river identified as the Tabal region, with many kingdoms under Assyrian control starting from the second half of 9th c. BC (Region 3) (Genz, 2011: 332). The MIA site's historical context is supported by two lead strips with Luwian hieroglyphs, found on its surface in $2006 \& 2010$, the northwesternmost findspot for the Iron Age version of this script (Aydoğan \& Hawkins, 2009; Omura, 2016: 20; Weeden, 2013). This might connect the community at Yassıhöyük with the MIA political region of Tabal (Region 3).

To sum up, the site is on the borderline between two different pottery cultures (Region 1 and 2) and almost in the middle between two political entities (Region 1 and 3) during the MIA. Yassihöyük could therefore provide a case study to observe any interaction between these three regions in Central Anatolia from the perspective based on both material and historical context. On the other hand, as Genz underscores (2011: 333), each site in Central Anatolia has its own chronology for the Iron Age rather than a common chronology which could be followed by all sites. It thus becomes complicated to coordinate a pottery study throughout Central Anatolia. My project might be a small contribution to establish a common MIA chronology by conducting a review of MIA pottery cultures 
associated with this historical context in Central Anatolia, taking Yassıhöyük as a case study. 